
\title{
25 Research Square \\ Thyroid function and thyroglobulin level in iodine deficient children of eastern Nepal
}

\section{Saroj Kunwar}

Modern Technical College

Saroj Khatiwada ( $\nabla$ khatiwadasaroj22@gmail.com )

Modern Technical College https://orcid.org/0000-0002-5158-9324

\section{Basanta Gelal}

B P Koirala Institute of Health Science

\section{Saroj Thapa}

B P Koirala Institute of Health Sciences

\section{Gaurishankar Shah}

B P Koirala Institute of Health Sciences

Nirmal Baral

B P Koirala Institute of Health Sciences

Madhab Lamsal

B P Koirala Institute of Health Sciences

\section{Research note}

Keywords: Children, lodine deficiency, Nepal, Thyroid dysfunction, Urinary iodine concentration (UIC)

Posted Date: April 23rd, 2020

DOI: https://doi.org/10.21203/rs.3.rs-24159/v1

License: (c) (1) This work is licensed under a Creative Commons Attribution 4.0 International License.

Read Full License 


\section{Abstract}

Objective: Both iodine deficiency and excess can negatively impact thyroid function. The present study was conducted to assess iodine nutrition among children and thyroid function in iodine deficient children.

Results: A total of 1012 school aged children (6-14 years) from several schools of Udayapur district were enrolled initially for the assessment of urinary iodine concentration (UIC). Blood samples ( $n=83$ ) were collected from a subgroup of children who had $\mathrm{UIC}<100 \mu \mathrm{g} / \mathrm{L}$ to measure serum thyroglobulin $(\mathrm{Tg})$, thyroid stimulating hormone (TSH), free triiodothyronine (fT3) and free thyroxine (fT4). Serum UIC was measured by ammonium persulfate digestion method and $\mathrm{Tg}, \mathrm{TSH}, \mathrm{fT} 4$ and $\mathrm{fT} 3$ were measured by ELISA kits from Diametra Company. The prevalence of insufficient UIC (UIC $<100 \mu \mathrm{g} / \mathrm{L})$ was $11.1 \%$ in school children's of Udayapur district. The median UIC was $236 \mu \mathrm{g} / \mathrm{L}$. The mean fT3, fT 4 and TSH among children with insufficient UIC were $2.55 \pm 0.43 \mathrm{pg} / \mathrm{mL}, 0.96 \pm 0.28 \mathrm{ng} / \mathrm{dL}$ and $3.60 \pm 1.44 \mathrm{mIU} / \mathrm{L}$ respectively. The Median Tg was $17.5 \mathrm{ng} / \mathrm{mL}$. Overt hypothyroidism and subclinical hypothyroidism was seen in $6 \%$ and $3.6 \%$ cases with $\mathrm{UIC}<100 \mu \mathrm{g} / \mathrm{L}$ respectively.

\section{Introduction}

lodine is an essential micronutrient required for production of thyroid hormones [1, 2]. lodine deficiency affects 2 billion people with 36.4\% being school age children [3]. lodine deficiency during pregnancy and childhood has severe consequences including developmental disorders, poor cognition and intellectual disability [4]. Supplementation of iodine in food or salt has led to significant reduction in iodine deficiency disorders worldwide [5].

Nepal has been continuously improving iodine nutrition after starting universal salt iodization program. A number of studies particularly in eastern Nepal show promising results in improvement of iodine deficiency as revealed by increase in median urinary iodine concentration (UIC) of school children [6-8]. However, there are also concerns about excess iodine intake in such population [9]. lodine deficiency or excess both affects thyroid function, so it is important to maintain thyroid function in such population [1]. In this study we specifically aimed to find the recent iodine status and thyroid function in the children with inadequate iodine intake (median $\mathrm{UIC}<100 \mu \mathrm{g} / \mathrm{L}$ and UIC:100-199 $\mu \mathrm{g} / \mathrm{L}$ are considered as inadequate iodine intake and adequate iodine intake respectively as per WHO criteria) in Udayapur district.

\section{Main Text}

This was a community based cross-sectional study conducted in school children during September 2014 to August 2015 in Udayapur district of eastern Nepal. The study was conducted by the department of biochemistry in collaboration with department of pediatrics of B. P. Koirala Institute of Health Sciences (BPKIHS), Dharan, Nepal. A multistage random sampling technique was used to enroll school children aged 6 to 14 years in the study. Total of 1012 children from 4 VDCs (Beltar, Basaha, Rampur and Chaudandi) of Udayapur district participated in the study. In the first stage, urine samples were collected 
from all participants and based on the UIC data, 83 blood samples out of 112 children who had UIC < $100 \mu \mathrm{g} / \mathrm{L}$ were collected to assess thyroid function and thyroglobulin level. The study was approved by Institutional Ethical Review Committee (IRC) of BPKIHS (Code No: IRC/422/014, Date-16/02/2015) and was conducted in accordance to Helsinki declaration of 1975.

A written informed consent was obtained from the guardian of children prior to participation in study. All the stake holders including participants were informed about the purpose of the study. All healthy school going children (aged 6-14 years of age) were included in the study. Children taking drugs that interfere in thyroid function, taking iodine supplement or with any severe illness were excluded. Anthropometric measurements (height and weight) were taken, and spot urine samples were collected from all participants. Urine samples were collected in a clean, tightly screw-capped plastic vial and transported to the biochemistry laboratory for analysis. Blood samples $(3 \mathrm{ml})$ were collected in plain vial by venipuncture following the standard protocol. Clotted blood was centrifuged at $3000 \mathrm{rpm}$ and serum was separated. Serum and urine samples were refrigerated at $-20^{\circ} \mathrm{C}$ until analysis. Urinary iodine concentration was estimated by ammonium persulfate digestion microplate (APDM) method using Sandell-Kolthoff's reaction [10]. Serum free tri-iodothyronine (T3), free tetra-iodothyronine (T4), TSH and thyroglobulin ( $\mathrm{Tg}$ ) were measured by ELISA using commercial kits (Diametra Company).

The data was analyzed using SPSS version 20.0. The data are presented in form of mean \pm SD, median with inter quartiles (IQR) and frequency (percentage). Chi-square test was applied to see statistical difference. Spearman's and Pearson's correlation analysis was used to find relationship between quantitative variables. $P$ value of $\leq 0.05$ was considered statistically significant at $95 \%$ confidence interval.

Total of 1012 school children (482 males and 530 females) from 4 VDC of Udayapur district participated in the study. The average \pm SD age, weight and height were $10.94 \pm 2.32$ years versus $10.7 \pm 2.31$ years, $28.5 \pm 7.82 \mathrm{~kg}$ versus $29.53 \pm 9.56 \mathrm{~kg}$ and $131.82 \pm 14.04 \mathrm{~cm}$ versus $131.48 \pm 14.80 \mathrm{~cm}$ in males and females respectively. The median UIC with IQR was $236.0 \mu \mathrm{g} / \mathrm{L}(156.0,331.38)$ indicating adequate iodine intake. The median UIC (IQR) among male and female children were $219 \mu \mathrm{g} / \mathrm{L}(149,335)$ and $248 \mu \mathrm{g} / \mathrm{L}(165,330)$ respectively. The UIC had significant positive correlation with the height $(r=0.098, p$ $=0.002)$ and weight $(r=0.0 .112, p<0.001)$ of the children.

Table 1 shows the classification of iodine nutrition status in the study participants according to modified WHO assessment criteria with adequate and more than adequate group merged as sufficient category [3]. The overall prevalence of iodine deficiency based on individual UIC cutoffs in our study was $11.1 \%$ (i.e severe, moderate and mild deficiency). 
Table 1

lodine status according to gender

\begin{tabular}{|c|c|c|c|c|c|c|c|}
\hline & & $\begin{array}{l}\text { Severe ID } \\
(< \\
20 \mu \mathrm{g} / \mathrm{L})\end{array}$ & $\begin{array}{l}\text { Moderate ID } \\
(20- \\
49 \mu \mathrm{g} / \mathrm{L})\end{array}$ & $\begin{array}{l}\text { Mild ID } \\
(50- \\
99 \mu \mathrm{g} / \mathrm{L})\end{array}$ & $\begin{array}{l}\text { Sufficient } \\
(100- \\
299 \mu \mathrm{g} / \mathrm{L})\end{array}$ & $\begin{array}{l}\text { Excessive } \\
(> \\
300 \mu \mathrm{g} / \mathrm{L})\end{array}$ & $\begin{array}{l}P \\
\text { value }\end{array}$ \\
\hline \multirow[t]{6}{*}{ Gender } & Male & 5 & 13 & 40 & 266 & 158 & \multirow[t]{4}{*}{0.5} \\
\hline & 482) & $(0.5 \%)$ & $(1.2 \%)$ & $(3.9 \%)$ & $(26.3 \%)$ & $(15.6 \%)$ & \\
\hline & \multirow{2}{*}{$\begin{array}{l}\text { Female } \\
(\mathrm{n}= \\
530)\end{array}$} & 4 & 19 & 31 & 291 & 185 & \\
\hline & & $(0.4 \%)$ & $(1.8 \%)$ & $(3.0 \%)$ & $(28.7 \%)$ & $(18.3 \%)$ & \\
\hline & Total & 9 & 32 & 71 & 557 & 343 & \\
\hline & $\begin{array}{l}(n=1 \\
1012)\end{array}$ & $(0.9 \%)$ & $(3.2 \%)$ & $(7.0 \%)$ & $(55.0 \%)$ & $(33.9 \%)$ & \\
\hline \multicolumn{8}{|c|}{ ID = lodine deficiency } \\
\hline \multicolumn{8}{|c|}{$\begin{array}{l}\text { The data is expressed as frequency (percentage). Chi-square test was used between gender and } \\
\text { iodine status at } 95 \% \text { confidence interval. }\end{array}$} \\
\hline
\end{tabular}

The mean fT3, fT4, TSH and median Tg (IQR) in children with insufficient UIC were $2.55 \pm 0.43 \mathrm{pg} / \mathrm{mL}$, $0.96 \pm 0.28 \mathrm{ng} / \mathrm{dL}, 3.60 \pm 1.44 \mathrm{mlU} / \mathrm{L}$, and $17.5(12,29.4) \mathrm{ng} / \mathrm{mL}$ respectively. Out of 83 participants with low UIC, 75 had normal thyroid function, 5 had overt hypothyroidism and 3 had subclinical hypothyroidism as shown in Table 2. Tg has positive correlation with fT3 $(r=0.273, p=0.013)$ as shown in Fig. 1.

Table 2

Thyroid function in children with insufficient UIC

\begin{tabular}{|c|c|c|c|c|c|}
\hline & & Normal & $\begin{array}{l}\text { Overt } \\
\text { hypothyroidism }\end{array}$ & $\begin{array}{l}\text { Subclinical } \\
\text { hypothyroidism }\end{array}$ & $\begin{array}{l}P \\
\text { value }\end{array}$ \\
\hline \multirow[t]{3}{*}{ Gender } & Males $(n=40)$ & $\begin{array}{l}36 \\
(43.4 \%)\end{array}$ & $2(2.4 \%)$ & $2(2.4 \%)$ & \multirow[t]{3}{*}{0.761} \\
\hline & $\begin{array}{l}\text { Females }(n= \\
43)\end{array}$ & $\begin{array}{l}39 \\
(46.9 \%)\end{array}$ & $3(3.6 \%)$ & $1(1.2 \%)$ & \\
\hline & Total $(n=83)$ & $\begin{array}{l}75 \\
(90.3 \%)\end{array}$ & $5(6.0 \%)$ & $3(3.6 \%)$ & \\
\hline \multicolumn{6}{|c|}{ UIC = Urinary iodine concentration } \\
\hline
\end{tabular}

lodine deficiency has remained as the most common cause of preventable brain damage in children worldwide [11]. Supplementation of iodine in salt through universal salt iodization has become effective in Nepal as shown by improving median UIC in the previous studies from eastern Nepal [6-8]. Median UIC 
indicates recent iodine intake and is used as marker of iodine status in the community settings. In the present study, median UIC was $236.0 \mu \mathrm{g} / \mathrm{L}$ which indicates sufficient iodine nutrition among children of this district. Previous report showed median UIC of $268.02 \mu \mathrm{g} / \mathrm{L}$ among children of this district [7].

In this study $11.1 \%$ children had UIC $<100 \mu \mathrm{g} / \mathrm{L}$ which is considered as iodine deficiency. In the previous study, iodine deficiency in this district was $12.7 \%$ [7]. National surveys conducted in Nepal in the year 1998, 2005 and 2007 depicted iodine deficiency in $43.6 \%, 27.4 \%$ and $19.4 \%$ school age children respectively [12]. In another study in eastern regions, Dhankuta and Dharan, iodine deficiency was $26.6 \%$ and $15.6 \%$ respectively among school children $[13,14]$. Our findings suggest improvement in iodine nutrition in this region over previous years. This reveals the effectiveness of universal salt iodization program in Nepal. The fluctuation in diet across different seasons are also said to affect UIC of population leading to variation of UIC across various seasons in the same population [15].

Thyroglobulin, a thyroid-specific protein and precursor in the synthesis of thyroid hormones, is also considered as a sensitive marker of the iodine status than UIC [16]. The median thyroglobulin level in the children with insufficient UIC was $17.5 \mathrm{ng} / \mathrm{mL}$. Our previous study among pregnant women of eastern Nepal reported median Tg of $6.5 \mathrm{ng} / \mathrm{mL}$ [17]. Thyroglobulin increment in plasma is also seen with thyroid mass, inflammation and hyperactivity of TSH [18].

We observed normal thyroid function in majority of children with iodine deficiency. Out of 83 children with insufficient UIC, 6\% $(n=5)$ had overt hypothyroidism and 3.6\% $(n=3)$ had subclinical hypothyroidism.

Previous studies by Shakya et al., Chaudhari et al., and Khatiwada et al. found subclinical hypothyroidism in $19.5 \%$ and $16.7 \%$ (in Morang and Sunsari respectively), 31.8\% and $25.59 \%$ (in Sunsari and Dhankuta respectively) and $17.6 \%$ respectively (in hilly regions) $[19,14,20]$. Thyroid dysfunction, specifically hypothyroidism was less common in this study than shown by our previous studies. This might be due to thyroid function assessment only in the subgroup with low UIC. In addition, there are other causative factors for thyroid disorders such as thyroid autoimmunity which might have been missed from this subgroup [17]. Thyroid function is said to be impaired in both the condition of iodine deficiency and excess [1].

We observed weak negative correlation of UIC with Tg level and thyroid hormones in children with insufficient UIC, and a positive correlation between thyroglobulin and fT3 $(r=0.273, p=0.013)$. In iodine deficient cases, thyroglobulin tends to rise due to hyperactivity of thyroid gland and TSH however thyroid gland may be able to adapt to short term iodine deficiency maintaining normal thyroid hormones [1].

In summary, we found adequate iodine nutrition among the school children with small fraction having recent iodine deficiency, with the majority of children showing normal thyroid function.

\section{Limitations}

The present study has several limitations. Individual UIC was used as a marker of iodine deficiency and thyroid function was not assessed in all the participants. Thyroglobulin was estimated in the children 
with low UIC and other causes of thyroid dysfunction were not investigated.

\section{Declarations}

Ethics approval and consent to participate

The study was approved by Institutional Ethical Review Committee (IRC) of BPKIHS (Code No: IRC/422/014). Written consent was taken from children's parent before participation.

\section{Consent for publication}

Not necessary

\section{Availability of data and material}

Data available on reasonable request.

\section{Competing interests}

None

\section{Funding}

None

\section{Author's contribution}

SK1, SK2, BG, NB and ML designed the study. SK1 and ST collected the samples. SK1 analyzed the samples. SK2 performed data analysis and drafted the manuscript. SK1 helped in drafting manuscript. All authors read and approved the final version of manuscript.

\section{Acknowledgements}

We kindly acknowledge all the participants of the study.

\section{Abbreviations}

APDM

Ammonium persulphate digestion method

Free T4

Free thyroxine

Free T3

Free triiodothyronine

$\mathrm{Tg}$

Thyroglobulin 
TSH

Thyroid stimulating hormone

UIC

Urinary iodine concentration

\section{References}

1. Chung HR. lodine and thyroid function. Ann Pediatr Endocrinol Metab. 2014;19(1):8-12. doi:10.6065/apem.2014.19.1.8.

2. Mullur R, Liu YY, Brent GA. Thyroid hormone regulation of metabolism. Physiol Rev. 2014;94(2):35582. doi:10.1152/physrev.00030.2013.

3. Zimmermann MB, Jooste PL, Pandav CS. lodine-deficiency disorders. Lancet. 2008;372(9645):125162. doi:10.1016/S0140-6736(08)61005-3.

4. Zimmermann MB. The effects of iodine deficiency in pregnancy and infancy. Paediatr Perinat Epidemiol. 2012;26(1):108-17. doi:10.1111/j.1365-3016.2012.01275.x.

5. Ershow AG, Skeaff SA, Merkel JM, Pehrsson PR. Development of Databases on lodine in Foods and Dietary Supplements. Nutrients. 2018;10(1). pii: E100. doi:10.3390/nu10010100.

6. Khatiwada S, Gelal B, Gautam S, Lamsal M, Baral N. lodine Status among School Children of remote Hilly regions of Nepal. Indian Pediatr. 2015;52(5):436-7.

7. Khatiwada S, Lamsal M, Gelal B, Gautam S, Nepal AK, Brodie D, et al. Anemia, Iron Deficiency and lodine Deficiency among Nepalese School Children. Indian J Pediatr. 2016;83(7):617-21. doi:10.1007/s12098-015-1924-y.

8. Khatiwada S, Gelal B, Shakya PR, Lamsal M, Baral N. Urinary lodine Excretion among Nepalese School Children in Terai Region. Indian J Pediatr. 2016;83(1):15-7. doi:10.1007/s12098-015-1755-x.

9. Shakya PR, Gelal B, Baral N. High iodine intakes in school children in Eastern Nepal. IDD Newsletter. 2011;39:10-3.

10. Ohashi T. Yamaki M, Pandav CS. Karmarkar MG, Irie M. Simple microplate method for determination of urinary iodine. Clin Chem. 2000;46(4):529-36.

11. Vincenzo T, Emilio T, Angelo VG, Carlo S, Francesco R, Brunella L, et al. Role of lodine, Selenium and Other Micronutrients in Thyroid Function and Disorders.Endocr Metab and Immune. Disord Drug Targets. 2009;9(3):277-94.

12. Ministry of Health and Population, Department of Health Services. Government of India and Alliance Nepal. National Survey and Impact Study for lodine Deficiency Disorders (IDD) and availability of iodized salt in Nepal; 2007.

13. Gelal B, Chaudhari RK, Nepal AK, Sah GS, Lamsal M, Brodie DA, et al. lodine deficiency disorders among primary school children in eastern Nepal. Indian J Pediatr. 2011;78(1):45-8. doi:10.1007/s12098-010-0239-2. 
14. Chaudhari RK, Gelal B, Brodie D, Baral N. Thyroid function and urinary iodine status in primary school age children of the hills and plains of Eastern Nepal. Indian Pediatr. 2012;49:332-3.

15. Als C, Haldimann M, Bürgi E, Donati F, Gerber H, Zimmerli B. Swiss pilot study of individual seasonal fluctuations of urinary iodine concentration over two years: is age-dependency linked to the major source of dietary iodine? Eur J Clin Nutr. 2003;57(5):636-46.

16. Ma ZF, Skeaff SA. Thyroglobulin as a biomarker of iodine deficiency: a review. Thyroid. 2014;24(8):1195-209. doi:10.1089/thy.2014.0052.

17. Chaudhary LN, Khatiwada S, Gelal B, Gautam S, Lamsal M, Pokharel H, et al. lodine and Thyroid Function Status, and Anti-thyroid Peroxidase Antibody among Pregnant Women in Eastern Nepal. J Nepal Health Res Counc. 2017;15(2):114-9.

18. Vejbjerg P, Knudsen N, Perrild H, Laurberg P, Carlé A, Pedersen IB, et al. Thyroglobulin as a marker of iodine nutrition status in the general population. Eur J Endocrinol. 2009;161(3):475-81. doi:10.1530/EJE-09-0262.

19. Shakya PR, Gelal B, Das BKL, Lamsal M, Pokharel PK, Nepal AK, et al. Urinary iodine excretion and thyroid function status in school age children of hilly and plain regions of Eastern Nepal. BMC Res Notes. 2015;8:374.

20. Khatiwada S, Gelal B, Baral N, Lamsal M. Association between iron status and thyroid function in Nepalese children. Thyroid Res. 2016;9:2. DOI:10.1186/s13044-016-0031-0.

\section{Figures}




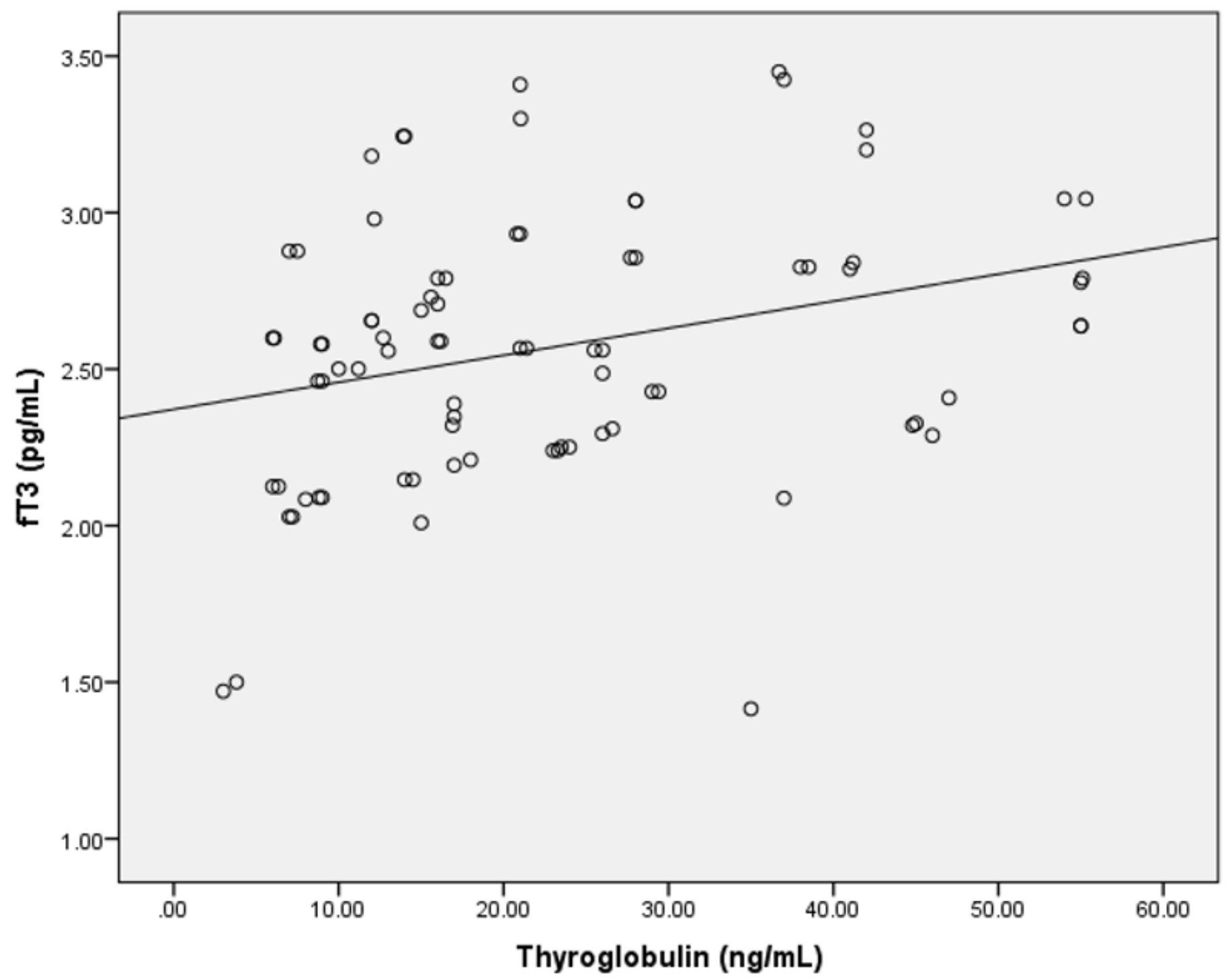

Figure 2

Correlation between serum fT3 and thyroglobulin. fT3=free triiodothyronine (T3). 